\title{
Covid-19 Outbreak on Malawi Perspective
}

\author{
George N. Chidimbah Munthali ${ }^{1,2,3 \star}$, Wu Xuelian ${ }^{2}$
}

\author{
${ }^{1}$ Mzuzu University Private Bag 201 Luwinga Mzuzu Malawi, MALAWI \\ ${ }^{2}$ Yangtze University Nanhuan road 1th, Jingzhou city, Hubei province, CHINA \\ ${ }^{3}$ Chidimbah Financial Consultants, MALAWI \\ *Corresponding Author: Huaitian07@outlook.com
}

Citation: Munthali GNC, Xuelian W. Covid-19 Outbreak on Malawi Perspective. Electron J Gen Med. 2020;17(4):em210. https://doi.org/10.29333/ejgm/7871

\begin{tabular}{|c|c|}
\hline ARTICLE INFO & ABSTRACT \\
\hline Received: 30 Mar. 2020 & On 31 December 2019 COVID-19 case was first reported in Wuhan China as a respiratory disease. With the \\
\hline Accepted: 1 Apr. 2020 & $\begin{array}{l}\text { declaration of World Health Organization (WHO) as a global pandemic, Covid-19 Virus is spreading globally at a } \\
\text { faster rate. Despite its in more than } 204 \text { countries in the world, Malawi as of } 31 \text { March } 2019 \text { is among the countries } \\
\text { that have not registered any case. Looking at its economic, political and health status its recommended that the } \\
\text { authorities should strengthen more preventive measures in order to prevent the pandemic to enter into Malawi. }\end{array}$ \\
\hline
\end{tabular}

Keywords: COVID-19, Malawi health system, Corona Virus, pandemic

\section{BACKGROUND}

On 31 December 2019 first case of new of pneumonia of corona virus was registered in Wuhan, Hubei province in China now known as the COVID-19 which is caused by Severe Acute Respiratory Syndrome Coronavirus 2 (SARS-CoV2), symptoms include cough, fever and shortness of breath (1-3). COVID-19 Virus is a kind of zoonotic pathogens that is able to be transmitted through both animal and human contacts $(3,5)$. On 11 March 2020 the World Health Organization (WHO) declared the COVID-19 as a global pandemic, since then COVID-19 cases has been increasing rapidly up to 697,244 confirmed cases, 33,257 deaths in over more than 204 countries as at 31 March (4). As a global pandemic many countries have taken necessary measures to prevent and control, in order to reduce the mortality rate and other impacts the virus is causing in all sectors of development within and beyond the borders of an economy, yet still there are few countries as at 31 March 2020 that they have not registered any case of COVID-19 and one of them is Malawi.

\section{CURRENT STATUS IN MALAWI}

Malawi is a landlocked country located in the southern part of Africa with a total population of close to 17.5 Million and its GDP of as at 7 billion USD representing 0.01 of the world's total GPD which also ranked it as one of the poor country in the world (6). Being in a region where all of its bordering countries have registered cases of Covid-19 the risk is high and that they is a lot of speculations about the virus in Malawi, and that many people are leaving with fear and anxiety, it therefore makes sense that regardless that the COVID-19 has not reached Malawi yet the government must put in place all the necessary measures that will help in the prevention of the pandemic. This perspective looks at the current situation of COVID-19 in Malawi as compared with other African countries situations.

\section{MALAWI HEALTH SYSTEM STATUS}

Malawi healthy system is under the Ministry of Healthy $(\mathrm{MOH})$ which is responsible and act as the overseeing body of all healthy related matters in the Country, while this is so the health services in Malawi are provided through the public under $\mathrm{MOH}$ and the private sector, the private sector is grouped by those specifically aimed at profit making and those not specifically aimed at profit making like mission hospital and other not profit making organization (6). In Malawi they are only four main Central hospitals that operate at high referral level where there is high expertise and specialists' attentions, from there comes District hospital in each and every district that also has some level of referral but not as compared to the central hospital, then lastly health Centre's, dispensaries and other village clinics that attends to small issues. Malawi has been for the past years faced with some other epidemics and pandemic and that it is still fighting some like Cholera and HIV/Aids (7). Despite this experience, COVID-19 is another kind of the pandemic that has seen world powerful economies with improved and high rated medical healthy system struggling to prevent and control the spread of the virus including running out of the testing material's, masks, ventilators and other essential medical equipment, as a results they is need for proper prevention measures to be implemented in order to avoid it and that necessary arrangements must be done in preparing the healthy system for the pandemic in case its registered in the country. The donation of testing kits, masks and other medical equipment's to be used to fight COVID-19 by the Alibaba foundation to all African countries has also boosted 
Malawi medical equipment's which currently is not sufficient enough (8).

\section{POLITICAL STATUS}

Recently the High court siting as Constitutional court in Malawi nullified the presidential elections which was followed by many demonstrations across the country (9). As the electoral body in Malawi announced the calendar for the reelections of presidential polls, the people are expected to go into the polls by July 2019 but with the outbreak COVID-19 the future is in dilemma as nobody knows as to when the pandemic will end, regardless of this situation, leaders are encouraged by the WHO to enforce preventive and control measures that they protect their citizens and one of it is lockdown which has proved to be a working measures for many countries (10). As such Malawi has already been declared as a state of disaster by the current leader in order to protect its citizen from the virus.

\section{ECONOMIC STATUS}

Due to the political instability the country economy has been negatively affected as many businesses were disturbed by demonstration as it was projected by the World bank (11). COVID-19 impacts have not only affected major economies, as a landlocked country, Malawi has also been affected as most of its raw materials, medical suppliers and other end products are imported from other countries (7). Malawi depends mostly on agriculture for its GDP and food security and currently most farmers are still in the process of farming with special interest to tobacco as the main cash crop and maize for food security, now with the COVID-19 will mean that even farmers will need to reduce and eventually stop all agriculture activities as one way of preventing the spread of the virus which is very difficult and will have huge negative impact on Malawi economy in the future $(12,13)$.

\section{OTHER AFRICAN COUNTRIES STATUS}

As at 31 March 2020, 40 countries out of 47 Countries in Africa had registered with COVID-19 cases, registering 3786 confirmed cases and 77 deaths in total (14). With the guidance of the WHO almost all their countries in Africa have responded to the calls and advises given by the WHO by starting to restricting and crossing all the land borders, sea and flights entries into and outside the countries and only allowing essential activities to be being transported (15). Furthermore, for example some countries like Tanzania, Algeria, Djibouti, Kenya, Morocco, Zambia, etc. have taken restrictions measures on public gatherings and internal travelling too, while some countries like Rwanda and South Africa have taken further measures on lockdown. Rwanda on Saturday 21 March announced 14 days lockdown while the South African government on Monday March 23 announced a 21 days countrywide lockdown in order to reduce the number of cases which are increasing at the faster rate, South Africa currently is the leading country with highest confirmed number of cases in the Africa continent, the full lockdown has made South Africa and Rwanda to be among the African Country which has joined other countries outside Africa like India, China, France, Italy, New Zealand, Spain, USA and Poland etc. in total lockdown
$(16,17)$. It looks that there is great coordination between the WHO and countries as the countries has shown much effort in combating this deadly pandemic by following the WHO measures.

\section{MALAWI STEPS TAKEN IN COMPARISON WITH OTHER AFRICAN COUNTRIES}

The Malawi government so far has taken some recommendable measures. Firstly, by appointing Special Cabinet Committee on Corona virus which started in operative on 7th March 2020 with an aim of providing a policy guidance and looking at all top-level matters concerning the COVID-19 pandemic (18) and it further announced the country as a state of disaster on March 21 2020, across the country they have banned street vending, public gatherings including religious gatherings, wedding ceremony, pubs etc. On 23rd March 2020 the Ministry of Education announced closure of all schools, colleges in both public and private sector in order to combat the COVID-19. Since the announcement of the state of emergency just like other African countries the Malawi government has also closed its land boarders and have restricted air flights with special announcement to suspend all international fights starting from 1 April 2020 whereby allowing only transportations of goods and services that are essential to the country. People have been also communicated on the prevention and control measures like to use masks, wash their hands with soap, use of sanitizer and reporting to the nearest hospitals if they have any unusual symptoms in order to improve their hygiene as some of the ways laid down in helping to prevent and control the Virus $(4,19)$, also self-quarantine measures has been put in place to all visitors that may arrive from high risk areas which is argued by many people that it's not effective way as people may not be abiding to selfquarantine properly as compared to if a government quarantine is provided, this is so because effective quarantine measures have also proved to be key in reducing the spread of the virus (20). Combating the COVID-19 is a challenging task to all the countries affected due to its mode of transmission, the rate at which cases and mortality rate are increasing each and every day in the whole world. Malawi therefore can learn to improve on its current measures upon looking at examples of other developing economies on the way they are preventing and controlling the virus and the way they are struggling to control it $(4,5,21)$, in continuation, though they is limited number of testing's kits but its recommended to review the ways of screening COVID-19 approach and testing of population that may have any symptoms at large (22) in order to fully be assured that we don't have any case and to fully prepare as new cases are keep of being reported each and every day.

\section{CONCLUSION}

COVID-19 as a global pandemic has brought a huge negative impact to all the sectors of the developments within countries and outside the boarders, its high time then that Countries work together and learn from each other on how to combat this pandemic. Malawi as one of developing nation should therefore continue and improve the current measures that are in place regardless of its economic impact which may 
brought in order to prevent the pandemic as it is been witnessed on how the developed and other developing countries with well medical systems are struggling to fight it, therefore prevention would be the best way for Malawi and other remaining countries that are yet to register the COVID-19 cases in order to avoid imported cases. Through working together each person taking his part by following all the WHO and specific countries measures that are put in place it is believed that this pandemic will be fought and we will win.

\section{ACKNOWLEDGEMENTS}

I would like to thank the editorial team for their great remarks they gave me on my submission which helped to improve my work. Gratitude also goes to my supervisor Wu Xuelian and Rivas Gama Daru for their encouragement they rendered when I was writing this Perspective, furthermore my gratitude goes to all the medical practioners, volunteers and everyone who is taking time and resources to help in fighting the COVID-19 virus pandemic.

\section{REFERENCES}

1. World Health Organization (WHO). Novel Coronavirus (2019-nCoV), Situation Report - 1, 21 January 2020. Available at: https://www.who.int/docs/default-source/ coronaviruse/situation-reports/20200121-sitrep-1-2019ncov.pdf?sfvrsn=20a99c10_4

2. World Health Organization (WHO). Report of the WHOChina Joint Mission on Coronavirus Disease 2019 (COVID19). Available at: https://www.who.int/docs/defaultsource/coronaviruse/who-china-joint-mission-on-covid19-final-report.pdf

3. Bhagavathula AS, Aldhaleei WA, Rahmani J, Mahabadi MA, Bandari DK. Novel Coronavirus (COVID-19) Knowledge and Perceptions: A Survey on Healthcare workers. medRxiv 2020. https://doi.org/10.1101/2020.03.09.20033381 PMCid: PMC7070221

4. World Health Organization (WHO). Coronavirus disease (COVID-19) outbreak situation. Available at: https://www. who.int/emergencies/diseases/novel-coronavirus-2019 (Accessed 31 March 2020).

5. Addi RA, Benksim A, Amine M, Cherkaoui M. COVID-19 Outbreak and Perspective in Morocco. Electron J Gen Med. 2020;17(4):em204. https://doi.org/10.29333/ejgm/7857

6. Makwero MT. Delivery of primary health care in Malawi. African J Prim Heal Care Fam Med. 2018;10(1):1799. https://doi.org/10.4102/phcfm.v10i1.1799 PMid:29943590 PMCid:PMC6018651

7. Unicef. Unicef Malawi Situation Report \#2. April 2017. Available at: https://www.unicef.org/appeals/files/ UNICEF_Malawi_Humanitarian_SitRep_30_April_2017.pdf
8. XinhuaNet. Jack Ma Foundation donates masks, testing kits to Africa for COVID-19 control. Available at: http://www.xinhuanet.com/english/2020-

03/17/c_138887624.htm (Accessed 31 March 2020).

9. US News. Malawi Court Nullifies Presidential Vote, Orders New One. Available at: https://www.usnews.com/ news/world/articles/2020-02-03/malawi-braces-for-courtruling-on-disputed-presidential-vote (Accessed 31 March 2020).

10. Sprott D. Impact of city and residential unit lockdowns on prevention and control of COVID-19. Block Caving - A Viable Altern. 2020;21(1):1-9. Available at: https://www.golder. com/insights/block-caving-a-viable-alternative/

11. World Bank Organization. The World Bank In Malawi. Available at: https://www.worldbank.org/en/country/ malawi/overview (Accessed 31 March 2020).

12. Centres for Disease Control and Prevention. CDC in Malawi. CDC-Atlanta. 2013;(Cdc):1-2. Available at: https://www.cdc. gov/globalhealth/countries/malawi/pdf/Malawi_Factshee t-p.pdf

13. Mucavele FG. True Contribution of Agriculture to Economic Growth and Poverty Reduction: Malawi, Mozambique and Zambia Synthesis Report. FANRPAN. 2013;1-22. Available at: https://www.jstor.org/stable/resrep00699

14. Fahmi I. \#Covid19 Coronavirus Disease 2019-71. DroneEmprit. 2020;2019(March):1-19. Available at: https://pers.droneemprit.id/covid19/

15. Information HE, Assessment R. COVID-19 COVID-19. :1-7. Available at: https://apps.who.int/iris/bitstream/handle/ 10665/331587/SITREP_COVID-19_WHOAFRO_20200325eng.pdf

16. AP News. Africa cases over 2,000 as South Africa rushes into lockdown. Available at: https://apnews.com/f84f45f29 be60b7d0ad583be7197bdac (Accessed 31 March 2020).

17. African News. Rwanda enforcing coronavirus lockdown. Available at: https://www.msn.com/en-xl/africa/africatop-stories/rwanda-enforcing-coronavirus-lockdown/arBB11BTJb (Accessed 31 March 2020).

18. Malawi Post. Presidential appointment Special Committee on Corona Virus. available at: https://www.maravipost. com/government-of-malawi-statement-on-coronavirusoutbreakcovid-19/ (Accessed 31 March 2020).

19. Watkins J. Preventing a covid-19 pandemic. BMJ. 2020;368. https://doi.org/doi:10.1136/bmj.m810 PMid:32111649

20. Hanna D, Huang Y. The Impact of SARS on Asian Economies. Asian Econ Pap. 2004;3(1):102-12. https://doi.org/10.1162/ 1535351041747978

21. Minh Duc N, Duc Ha H, Anh Tuan T, Lien Bang MT, Hong Duc P, Minh Thong P. From First COVID-19 Case to Current Outbreak: A Vietnamese Report. Electron J Gen Med. 2020;17(4):em208. https://doi.org/10.29333/ejgm/7867

22. Ait Addi R, Benksim A, Amine M, Cherkaoui $M$. Asymptomatic COVID-19 Infection Management: The Key to Stop COVID-19. J Clin Exp Invest. 2020;11(3):em00737. https://doi.org/10.5799/jcei/7866 